\title{
Bias wanted! Examining people's information exposure, quality expectations and bias perceptions in the context of the refugees' debate among different segments of the German population
}

\author{
${ }^{*}$ DOROTHEE ARLT and JENS WOLLING
}

\begin{abstract}
The growing number of refugees entering Europe since 2015 has quickly ignited a heated public debate on refugees in Germany. Against the backdrop of the media's information and opinionforming function, this paper examines the importance of mainstream and social media among different segments of the German population. Applying cluster analysis to survey data $(n=$ 1,579), six clusters with specific attitude-behavior combinations concerning the refugee issue were identified: Pro-Refugee Activists, Passive-Affirmative Mainstream, Directly-Involved Ambivalents, Passive-Worried Mainstream, Worried Agitators, and Anti-Refugee Activists. The results show that these clusters differ both in terms of socio-demographic and political characteristics as well as in terms of people's issue-specific media usage, expectations, and evaluations of media coverage. Moreover, the findings indicate that social media play a problematic role in the debate as they seem to reinforce people's pre-existing attitudes toward refugees. The implications of these findings for public debate on refugees are also discussed.
\end{abstract}

Keywords: public debate on refugees, mainstream media, social media, quality expectations, bias perceptions, typology

\section{Introduction}

The increasing number of refugees coming to Europe since 2015 and the question of how to handle this challenge have become one of the most controversially discussed issues in Europe at the beginning of the century. In Germany, in particular, the public debate has become increasingly heated since difficulties relating to accommodating and integrating refugees are becoming more evident. In this debate, the mass media play a major role and are required to accomplish fundamental functions.

Following the very early ideas of Lasswell (1948) and Wright (1960), one of the most crucial functions of mass communication is surveillance of the environment, which basically refers to the media's information and news-providing function. Thus, the news media perform the function of informing the public about relevant public affairs and political issues (e.g., Patterson and Seib, 2005), thereby creating public awareness of relevant problems (Iyengar et al., 2010). Consequently, journalism actively contributes to a functioning democracy as the information provided empowers citizens to form political opinions and to participate in public discourse (e.g., McNair, 2009). As most people do not have personal contact or experiences with refugees, the media have become the main source of information on the contested refugee issue. Consequently, the media, with its information and opinion-forming function, play a

\footnotetext{
* Dorothee Arlt, Institute of Communication and Media Studies, Universty of Bern, dorothee.arlt@ikmb.unibe.ch.

Jens Wolling, Institut für Medien und Kommunikationswissenschaft, Technische Universität Ilmenau, jens.wolling@tu-ilmenau.de.
} 
crucial role in providing full, fair, and understandable information on the issue, which enables the public to formulate meaningful opinions and to participate in public debate.

From a normative perspective, the quality of the media content in terms of the media's performance is assessed on the basis of the functions fulfilled by journalism in democratic societies. Media coverage should be neutral and balanced (Arnold, 2009; McQuail, 1992). While neutrality refers to an objective presentation of facts so that journalists neither support nor repudiate the subject of their report (Westerståhl, 1983, p. 420), balance refers to equality in the selection of information, giving equal attention to the main protagonists involved in public discourse (McQuail, 1992). Regarding the actual debate, balance suggests that journalists should include in their coverage the views and opinions of all sides of the controversy on refugees. Moreover, the media have an integrative function as they facilitate public discourse that enables citizens to understand each other and overcome political, national, and cultural cleavages. Thus, the media are also relevant agents of social integration (e.g., Maletzke, 2002; Ronneberger, 2002), in particular, for those of new immigrants into a society (e.g., Becker, 1998; Geissler and Pöttker, 2009). However, the media can also have negative effects as they have the power to shape and cultivate racial and ethnic stereotypes and prejudices (e.g., Mastro, 2009). Thus, comprehensive, balanced, and neutral media coverage has become a significant precondition for achieving peaceful coexistence, mutual understanding, and the successful integration of refugees in host societies.

Nevertheless, the reality of mass media reporting with respect to the information, opinion-forming, and social integration function appears to be different, as the production of mass media content is influenced by a variety of internal and external factors (Shoemaker and Reese, 2014). Especially in the context of research on news selection, it is known that conflict, and especially controversy, is one of the most important factors influencing journalists' decision-making on the selection of national news and information for reporting (e.g., Eilders, 2006, p. 8; Galtung and Ruge, 1965; Staab, 1990). Thus, based on previous findings from news value research, it seems more likely that the media will give more attention to an issue if it is highly contested among political actors, thereby stimulating oppositional sides that result in public controversy. This is the case in the refugee issue. Parties, organizations, and people with pronounced, untempered, and even extreme standpoints on the topic have a good chance of voicing their opinions and positions in the media. Regarding the actual debate on refugees, this means that especially those who strictly oppose the reception of refugees and those who welcome refugees without restraint might receive more media attention than those representing balanced perspectives. This tendency is further intensified by the influence of other news factors such as negativism, damage, and protest, on the one hand, and unexpectedness and success/benefits, on the other (e.g., Eilders, 2006, p. 8; Ruhrmann, Woelke, Maier, and Diehlmann, 2003; Staab, 1990).

Thus, with the media simultaneously reporting on the impressive citizens' engagement in favor of the integration of refugees alongside furious protests demanding stricter refugee policies, the public might get the impression that there are two large groups with opposing viewpoints on the refugee debate: strict opponents and convinced advocates. Such a picture of a polarized public might influence public opinion, and like a self-fulfilling prophecy, it might provoke the emergence of a divided society concerning the refugee issue.

However, it is reasonable to expect that besides these full-throated counterparts, there are other segments in society with less pronounced or even ambivalent views on the issue. Nevertheless, the number and size of groups with specific combinations of opinions and behaviors, their socio-demographic profiles and communication behavior are currently unknown. To understand the dynamics of the public debate on the refugee issue, it is important to identify these groups and determine their size. It is necessary to ascertain the characteristics of the groups and to learn about their media selection and media evaluations because the 
information provided by the media they select and the conversations conducted through the media they share will shape the discourse on refugees as well as the public policy on the issue.

In view of previous research on the selection and reception of news it is well known that people's selective exploration and consumption of information is guided by their pre-existing attitudes and political predispositions to reinforce and defend existing worldviews (e.g., Iyengar and Hahn, 2009; Stroud, 2008), and that the outcomes of this media selectivity again affect peoples' future 'selection of and attention to media content' (Slater, 2007, p. 281). Furthermore, studies on the audience perspective of media quality that are closely related to the uses-andgratification-approach (e.g., Katz, Blumler, and Gurevitch, 1974) and the expectancy-valuemodel (e.g., Palmgreen and Rayburn, 1982) have shown that the audience varies both in their subjective needs and quality expectations as well as in their individual reception and evaluation of media content (e.g., Jungnickel, 2011; Wolling, 2009).

Thus, to gain a deeper insight into the drivers of the public discourse on refugees from an audience research perspective, this paper proceeds as follows: First, we develop a typology identifying groups of persons (clusters) sharing similar attitudes and showing comparable behaviors in terms of the refugee debate. Second, we describe these clusters in terms of their socio-demographic and political characteristics. Third, the media use behaviors of the identified clusters are investigated. As the refugee issue is controversially discussed in various media sources, the selective exposure to issue-specific information becomes of particular interest. Therefore, we examine the communication channels and media outlets that the different clusters rely on to inform themselves about the refugee issue. Fourth, as the role of the media in the refugee debate has been fundamentally criticized, especially by the opponents of the "welcome policy", we examine the differences between the identified groups regarding their expectations on how the media should cover the issue as well as their evaluation of actual media content in relation to the refugee issue. Taken together, this paper aims to answer the following three research questions:

RQ1. Which population segments (clusters) with specific attitude-behavior combinations concerning the refugee issue can be identified among the German population?

$R Q 2$. Do the clusters differ in terms of their socio-demographic and political characteristics? RQ3. Do these clusters differ in terms of their issue-specific media usage?

$R Q 4$. Do these clusters differ in terms of their expectations and evaluation of the media coverage on the refugee issue?

\section{The typological approach}

The fundamental idea in developing a typology is to identify patterns or structures among objects like newspaper articles or - as in our case - among groups of people (e.g., Everitt, Landau, Leese, and Stahl, 2011). In a typology of persons, individuals are grouped together in such a way that people within one group have similar personal characteristics, like attitudes or behaviors, while at the same time the group members can be clearly distinguished from members of other groups concerning these characteristics. Consequently, each group represents another type. The types were identified from selected indicators assumed to be relevant for the respective typology. Selecting suitable variables to identify a meaningful typology depends on the object under investigation. Convenient variables for identifying an environment-related attitude-behavior typology (e.g., Hefner, 2013; Leiserowitz, Maibach, Roser-Renouf, and Smith, 2011; Metag, Füchslin, and Schäfer, 2015) differ from suitable indicators for obtaining a typology of (political) communication-behavior (e.g., Emmer, Füting, and Vowe, 2006; Hasebrink and Domeyer, 2012; Hasebrink and Popp, 2006; Oehmichen and Ridder, 2010; Taddicken and Reif, 2016). 
In this study, we aim to identify groups of people showing different views and behaviors concerning the refugee issue. We argue that identifying the segments, determining their size, knowing their characteristics, and learning about their media use and media evaluation are crucial for understanding the structure and development of the public debate on refugees.

\section{Typology building: Attitudes and behaviors}

To identify the relevant attitudinal dimensions, this paper considers previous research on proand anti-immigrant attitudes that measures people's attitudes towards immigrants in the context of "group threat theory" and the "threat-benefit model" in terms of perceived threats and benefits (e.g., Esses, Dovidio, Jackson, and Armstrong, 2001; European Social Survey, 2015; Hainmueller and Hopkins, 2014; Tartakovsky and Walsh, 2016). For example, people who perceive refugees as an economic threat (e.g., negative consequences for the economy or fear of losing jobs) or a symbolic threat (e.g., perceived incompatibility of belief systems or cultural values) are considered to have a more negative attitude toward immigrants. In contrast, people who perceive immigrants as rather beneficial because they are expected to improve the economic situation of the country or enrich cultural diversity have more positive attitudes toward immigrants. Transferring previous research on immigration in general to the current refugee situation in Germany, we assume that whether German citizens welcome refugees to the country depends on people's perceptions of refugees as either threatening or beneficial in terms of economic, cultural, or personal aspects.

Referring to theoretical approaches that examine the relationship between attitudes and behaviors, attitudes are often defined as someone's psychological tendency, which is expressed in a positive or negative evaluation of a particular person, object, or situation (Eagly and Chaiken, 1993). These evaluations can manifest on a cognitive, affective, or behavioral level (Rosenberg and Hovland, 1960) whereby attitudes become externally visible in people's concrete behaviors and activities. Thus, attitudes can be a predictor for people's behaviors and activities. The presence of attitude-behavior-relations has already been supported empirically by various meta-analyses (Kim and Hunter, 1993; Kraus, 1995), whereas the relationship seems to be stronger when peoples' attitudes are confident and have been formed on behavior-relevant information (Glasman and Albarracín, 2006). From a communication studies’ perspective, such behaviors and activities have a predominantly communicational character and can be understood as specific ways of communication (Wolling and Emmer, 2014). Communication can occur either between the domestic population and the refugees in the form of interpersonal interactions, or it can take place as an interpersonal debate between the members of the domestic population about refugees. Furthermore, it can be directed at a broader public as an attempt to influence public opinion and political decision-making.

\section{Description of clusters}

The second group of variables applied in the analysis was used to describe characteristics of the clusters. Therefore, the relevant characteristics of the cluster members, such as sociodemographics, values, or personal traits, were used. In our case, we used socio-demographic variables like age, sex, and education and variables relating to politics, such as political interest, political orientation, and party preference, to describe the clusters. An important outcome of these descriptive analyses was the invention of group-names characterizing the persons within the clusters. Moreover, we analyzed a bunch of media-related variables that have already been demonstrated as being of relevance to understanding the peculiarity of the clusters in previous studies. 
For example, Hefner (2013) shows that different groups of persons with varying environment-related attitudes demonstrate differences in media use and motivations. However, studies on people's attitudes toward climate change in the US and Germany have shownd that different segments vary in terms of their exposure to issue-specific information, their evaluations of the quality of media coverage, their trust in different information sources, and the frequency of active searches for information on the issue (e.g., Leiserowitz et al., 2011; Metag et al., 2015). These findings support the notion that media and communication variables could aid in understanding the specifics of the clusters. Therefore, we considered the following communicational behaviors as relevant. First, regarding the media's information function, we examined how much information citizens receive on the refugee issue from traditional mainstream media, on the one hand, and from social media as an alternative information source, on the other. Second, with regard to the media's opinion-forming and integration functions, we sought to explain how strongly people's expectations and evaluations of the media coverage on refugees differed among various population segments. Do people in one cluster expect the media to emphasize the problems with refugees while those in other clusters expect the media to put a stronger emphasis on the benefits - for instance, examples of successful integration?

That recipients differed not only in their media usage behaviors but also in their individual quality expectations has been shown in various studies that examine media quality from an audience perspective (for an overview, see Voigt, 2016). In line with the Theory of Subjective Quality Assessment (TSQA) (Wolling, 2009), recipients' quality expectations refer to people's subjective desire in terms of what the media coverage - in this case, on the refugee issue - should look like. In line with previous research on subjective quality assessments, such expectations have been measured using so-called "arcs of tension" (Wolling, 2009), providing respondents with either-or alternatives, demanding them to make decisions relating to how journalists should report on an issue. Moreover, the question arises as to whether the tone in the media coverage on refugees is perceived differently by the members of the various clusters.

Based on media bias research, it can be expected that people from both sides of a controversy will perceive the media as biased against their view (e.g., Perloff, 2015; Vallone, Ross, and Lepper, 1985). That this holds true also for the immigration issue has already been demonstrated by McKeever, Riffe, and Carpentier (2012). Their results show that people holding negative attitudes towards immigrants perceive the media as biased in favor of immigrants and thus hostile against their views.

\section{Data and method}

For the development of the typology, data from a quantitative online access panel administrated by respondi AG were used. The data gathering took place between 1 and 10 February 2016. Based on quotes for age, sex, education, and place of residence, a sample $(n=1,579)$ representing the German-speaking over-18 online population was obtained. The operationalization of the variables used to identify the clusters and some basic descriptive results are presented in Table 1.

\section{Table 1}

The operationalizations of the socio-demographic and media-related variables used to characterize the clusters are displayed in Table 2. The sample consists of $50 \%$ men and $50 \%$ women between 18 and 82 years of age (average: 44 years). Formal educational levels were distributed as follows among the respondents: $42 \%$ low, $22 \%$ middle, $9 \%$ high secondary school degree, and $27 \%$ university degree. Regarding political orientation, the majority of respondents 
positioned themselves in the middle of the political spectrum (42\%), while 35\% tended more to the left and $23 \%$ more to the right $(\mathrm{M}=3.8, \mathrm{SD}=1.2)$.

Public television and radio were the most important traditional mass media sources of information concerning the refugee issue. It is remarkable that the amount of Facebook and private television use was almost at the same level. Even the reception of user comments as a source for information was not far behind the use of newspapers.

The desired characteristics of the coverage varied, but on some dimensions, there was significant agreement, for example, that the media should cover the topic without restraint and journalists should give ordinary people a voice. Concerning the perception of the coverage, the overall evaluation was positive. On average, those questioned perceived the content as relatively balanced.

\section{Table 2}

\section{Development of the typology}

The application of cluster analysis is required to identify homogeneous segments in the German population in terms of their attitudes toward the refugee issue. Previous research has shown that when large samples - as in this case - are analyzed the identified clusters may vary considerably depending on the cluster method that has been used. Therefore, to overcome this methodical weakness we used different types of cluster analyses to attain a stable cluster solution. We started with a hierarchical cluster analysis using Ward's method and Euclidean distance. To determine the appropriate number of segments, we used the elbow criterion and identified six clusters. As cluster analyses are sometimes sensitive to the order of cases in the dataset, we resorted the cases and repeated the analyses. With the re-sorted data, we obtained the same results as before; the clusters thus remained unchanged. In the next step, we applied the two-step cluster analysis with log-likelihood as a distance measure. This method is recommended for larger samples (Bacher, Pöge, and Wenzig, 2010). Furthermore, the two-step cluster method has the advantage of suggesting a suitable number of clusters to the researcher. Nevertheless, in our case, the proposed result of a three-cluster solution was not convincing. We therefore decided to fix the numbers of clusters at six and increased the maximum number of branches to ten. With these adjustments, we obtained a result comparable to using Ward's method. Notwithstanding, there were some differences between the determined clusters obtained by the two methods. By comparing the characteristics of the differing clusters, we found the groups identified by the two-step cluster approach more consistent and meaningful. We thus decided to stay with the six-cluster solution obtained with the adjusted two-step cluster method (Table 3).

\section{Results}

\section{A typology of Germans' attitudes and behaviors concerning the refugee issue}

Our first research question asks which attitude-behavior types concerning the refugee issue can be found among the German population. Table 3 shows the six clusters found in the German population and their characteristics concerning the variables used for identifying the clusters; further descriptive results illustrating the clusters are presented in Table 4.

The first cluster is labelled Pro-Refugee Activists $(\mathrm{n}=177)$. People in this group take the most political actions to support refugees and the second most discursive actions in the refugee debate. Their political attitudes are consistent with their engagement: They score highest on positive and lowest on negative attitudes toward refugees. The Passive-Affirmative 
Mainstream $(n=625)$ formed the largest cluster among the German population, with $41 \%$. As people in this group score the second highest on positive and the second lowest on negative attitudes toward refugees, they show a similar attitude structure as the Pro-Refugee Activists. However, despite their rather affirmative attitudes, the majority of the German population is inherently passive about the refugee debate. People belonging to this cluster do not take any political or discursive actions, nor do they engage directly with refugees. Likewise, the PassiveWorried Mainstream ( $\mathrm{n}=429$ ), which made up $28 \%$, was the second largest group in the German population to remain completely passive in the debate by not taking any action. The significant difference is, however, that people's concerns were reflected in their strong negative attitudes toward refugees.

Between these two huge clusters, a much smaller one emerged: Directly-Involved Ambivalents $(\mathrm{n}=69)$. It included people who did not only take political and discursive actions but who also had intense personal contacts with refugees, communicating with them in various situations and talking with other Germans about their experience. Direct, frequent communication with and about refugees might also be the reason why people in this group showed rather ambivalent attitudes toward refugees. One might argue that people who are constantly in contact with refugees see both the problems and the opportunities, and thus, they know that neither panic nor enthusiasm is an adequate reaction to the challenge.

The fifth cluster, the Worried Agitators ( $\mathrm{n}=199)$, scored the second highest on negative attitudes and the second lowest on positive attitudes towards refugees. They showed a comparable attitude structure to the Passive-Worried Mainstream, but in contrast, they were not passive. Rather, they actively expressed their anxieties through interpersonal communication about the refugee issue and took discursive actions. The last cluster, the AntiRefugee Activists $(\mathrm{n}=40)$ were a small radical group, heavily engaged in taking political and discursive actions against refugees. They showed the strongest negative and the weakest positive attitudes. Thus, this group represented a counterpart to the Pro-Refugee Activists. The findings also reveal that although the Anti-Refugee Activists were the most politically active group, they also formed the smallest cluster in the German population, with not more than three percent.

\section{Table 3}

\section{Differences between clusters with specific attitude-behavior combinations}

Our additional research questions asked whether clusters differ in terms of their sociodemographic and political characteristics (RQ2), their issue-specific media usage (RQ3) as well as their expectations and evaluations of the media coverage on the refugee issue (RQ4), which are addressed in the following cluster descriptions. Furthermore, analysis of variance and posthoc tests, as well as $\mathrm{Chi}^{2}$-tests documented in Table 4, revealed highly significant differences between different clusters for almost all variables.

Pro-refugee activists. 56\% of this cluster are male, and its members are on average 44 years old. It comprises a high proportion of the higher educated (56\%) and economically wellsituated people. Regarding political attributes, the members of this cluster have an aboveaverage interest in politics, are considerably closer to the political left, and show no sympathy for the right-wing populist-party AfD (Alternative for Germany). This group receives most of its information about refugees from public television broadcasts and, compared to all the other clusters, the least amount of information from private television programs. For Pro-Refugee Activists, Facebook and user comments are the most important social media sources of information about refugees. Regarding their expectations on how journalists should cover the refugee issue, this cluster has clear preferences: They do not want the media to focus on risks 
and problems. Compared to the other clusters, they are also less interested in the opinions of ordinary people and less convinced that the media should cover the issue without restraint. Taken together, they want to see a positive and optimistic image of refugees. In their perspective, the media do not fulfil these expectations. This cluster thus evaluates the coverage as overly negative.

Passive-affirmative mainstream. With regard to the socio-demographic variables, this group shows no striking characteristics. Age and income are close to the mean, and only members' educational level is somewhat higher than the average. This group does not have a very high interest in politics, and the political orientation is slightly left from center. In terms of information behavior, the Passive-Affirmative Mainstream, together with the PassiveWorried Mainstream, received the least information about the refugee issue from the various mass media. The same applies to information from social media. With regard to their expectations in relation to the media, this group also calls for a predominantly favorable coverage of refugees. The members of this cluster do not want journalists to highlight problems and risks or to air the positions of political extremists. However, in contrast to the Pro-Refugee Activists, they want the media to be less biased. Moreover, like the Pro-Refugee Activists, this cluster perceives the media coverage about the refugee issue as somewhat overly negative.

Directly-involved ambivalents. This cluster consists mainly of younger, higher educated, better earning men who are highly interested in politics. Concerning their political orientation, they can be found in the middle of the political spectrum. In respect of issue-specific media exposure, this group is the most involved and scores above average on all information channels - both mass media and social media. Compared to the other clusters, Directly-Involved Ambivalents receive the most information from public television services, newspapers, and the radio. Members of this group are not only active on Facebook and read user comments, but they are also relatively engaged in using Twitter and YouTube as information channels on the refugee issue. Compared to the two clusters described above, this group is more interested in a balanced coverage. They do not want the media to overestimate the risks and problems, but they expect the media to pay more attention to what ordinary people think, and believe that journalists should report without any constraints. Nevertheless, they also do not want the media to air the views of radical voices. Noteworthy, Directly-Involved Ambivalents do not only demand a balanced coverage, they also evaluate the actual media coverage as almost adequate, neither too positive nor overly negative.

\section{Table 4}

Passive-worried mainstream. This cluster is predominantly female. It has, on average, the oldest (47 years) members as well as the lowest proportion of higher educated members (20\%). Their income and political interest are below average. Concerning political ideology, they are placed exactly in the center of the scale. As mentioned earlier, this group - together with the Passive-Affirmative Mainstream - receives very little information about the refugee debate from mass media outlets. The same holds true for social media. However, although rather uninformed, this group has clear preferences in terms of how the issue should be covered. For instance, group members believe that journalists should be unconstrained, should emphasize risks and problems, and should give a voice to ordinary people. Along with their desire that the media should more strongly highlight the negative aspects of the refugee issue, group members consistently perceive the actual media coverage on the refugee issue as overly positive.

Worried agitators. Concerning age, gender, and income, this cluster is unremarkable and close to the average of the entire sample. However, the average educational level in this group is low, with just $22 \%$ having obtained a higher education qualification. With regard to their political orientation, Worried Agitators belong more to the right wing, with about $40 \%$ of 
members being sympathetic to the xenophobic right wing AfD. Regarding their mass mediaoriented information behavior, this group is similar to the Directly-Involved Ambivalents. A considerable part of this cluster relies heavily on mass media information. However, for this cluster, as all other groups, Facebook is an even more important source of information about the refugee issue. Besides Facebook, user comments are the second most important social media source for them. YouTube and Twitter are of much lower relevance. With respect to their demands concerning appropriate coverage, the members of this cluster show even more biased preferences than the Passive-Worried Mainstream. They do not only want journalists to highlight the risks and problems and to interview ordinary people concerning their opinion on the refugee issue, but a majority of the members also demand that media space be granted to extremists. Not surprisingly, Worried Agitators perceive the media coverage as biased against their views by reporting an overly positive standpoint on the refugee issue.

Anti-refugee activists. Even more pronounced are the key political characteristics of the last group. People in this group show the strongest political right-wing orientation and are unsurprisingly the strongest sympathizers with the AfD (73\%). The most striking finding is, however, that people in this cluster rely more on social media to receive information about refugees - above all on Facebook and user comments - than the members of all the other clusters. In contrast, traditional mass media play a less important role. This group almost consistently demands that the media cover the topic in a skewed manner. They would like journalists to report without restraint, to exclusively emphasize the risks and problems, and to give a voice to people with radical attitudes. Regarding their evaluations of the media coverage, this group has the strongest perception that media coverage about the refugee issue is far too positive and thus biased against their views.

\section{Discussion}

At least since 2015, the refugee issue has become a very prominent media topic. Not only has the issue been controversially debated, but the actions taken by the different segments of society have also been fundamentally oppositional. On the one hand, the media has portrayed people as welcoming and supportive of refugees. On the other hand, they have fed information about xenophobic aggressions against refugees and homes for asylum seekers. This coverage might lead to the impression that the German public is extremely polarized. Nevertheless, the findings of our analyses show that the vast majority of Germans are somewhat in between these two extremes. Relatively small groups of society (pro- and anti-refugee activists) dominate the public debate. However, the distribution of attitudes towards refugees underpins the notion of a divided society. Moreover, the members of the two unengaged mainstream groups hold categorically antagonistic opinions on the topic. The refugee topic is politicized: A remarkable coincidence between general political attitudes, party preference, and issues relating to attitudes can be observed.

However, political ideology is not the only factor that separates supporters and opponents. A second - probably even more significant - difference exists with respect to social aspects. A deep social gap concerning education and income can be observed between supporters and opponents. The refugee issue bears the risk of provoking a fundamental social conflict, evoking a threat to social cohesion.

Regarding the mass media, the findings show that the traditional news sources play a crucial role in informing the public about the issue. Even the two unengaged mainstream groups reported that they received a considerable amount of information about the topic from the mass media. Surprisingly, even those who criticized the media for being biased (especially the Worried Agitators and the Anti-Refugee Activists) rely heavily on the traditional mass media for information. However, these detractors, who blame the media for an overly positive 
coverage about the topic, do not restrict themselves to the traditional media. These groups have a preponderance of heavy users of social media channels, which are used as additional sources of information. Thus, this finding empirically underscores the need of future hostile media research to take the previously neglected role of social media into consideration, as Perloff (2015, p. 719) has promoted in his recent literature review. Notwithstanding, social media appear to play a problematic role in the debate. They operate like "echo chambers" (Colleoni, Rozza, and Arvidsson, 2014; Garrett, 2009), in which people are mostly exposed to information reinforcing the pre-existing attitudes of their users. It thus seems plausible to assume that social media usage might also influence evaluations of the traditional mass media. As social media users are mostly connected with like-minded people, it is of low probability that they come in contact with arguments that challenge their prejudices. Thus, in social media fora, people come to believe that their opinion is supported by a vast majority. Against this background, even a very neutral and balanced coverage will be perceived as unacceptably biased. This finding indicates that the use of social media probably reinforces the hostile media effect. Indeed, the two mainstream groups used less traditional media sources to stay informed; however, they are less addicted to social media. As their perspective is less distorted by homogeneous groups of likeminded people, they perceive the media as less biased. Nevertheless, as the example of the Directly-Involved Ambivalents demonstrates, there is no determining effect of social-media use on political radicalism. Members of this group are heavy users of social media but remain open to different perspectives.

From a normative perspective as well as in relation to recipients' prospects, it is common sense that the media should be neutral and objective. The findings of this study demonstrate that besides this abstract consensus, there is little agreement regarding desired characteristics of media coverage. People claim that they want unbiased media, but when asked what unbiased coverage should look like, the notions are far more inconsistent, indistinct, and murky. Some want the media to focus on risks while others would like a focus on opportunities. Some want the media to cover the topic without any constraints while others want a more cautious coverage. These desires are closely related to people's attitudes. Those who are already worried expect the media to focus on problems while those who have a favorable view want the media to draw an optimistic picture. Should the media act accordingly, anxious citizens would become even more anxious while enthusiasts would fail to gain awareness of the existing problems. Taken together, people perceive the media as biased against their view, and they want the media to be biased in favor of their opinion. These findings are in line with the hostile media hypothesis, but they go a step further to indicate the precarious position of the media: People do not only perceive the media as biased; they also want the media to be biased in favor of their positions.

Why do people want the media to be biased in line with their attitudes? One explanation could be that people want to avoid dissonance. Perhaps it is even more plausible that they fear that public opinion can be misguided by the media if the topic is covered inappropriately. This interpretation would be consistent with research on the Third-Person Effect and the Influenceof-Presumed-Media-Influence Approach (Tal-Or, Tsfati, and Gunther, 2009). Finally, the cluster consisting of Directly-Involved Ambivalents should be discussed. This group is characterized by highly involved members who predominate in terms of direct contact with refugees. They are the only ones who have intense contacts with the refugees. Besides their widespread personal experience, they are also well informed by traditional mass media. Furthermore, they talk with fellow citizens about refugees, and they seek information on social media. This comprehensive, mediated, and direct experience allows them to develop a differentiated view of reality. As they have gained multifaceted insights from a variety of personal and mediated sources, they are able to develop a balanced view. They do not want to ignore the problems, but they also see the positive dimensions. To develop a realistic view, a 
balanced coverage is needed, which is what they expect from the media as well as what they observe. At the very least, these well-informed citizens acknowledge that the media does a good job.

Although this study provides some relevant insights into the role of communication in the context of the German refugee debate at the beginning of 2016, it has some weaknesses and leaves some important questions unanswered that should be addressed in future research. The first limitation relates to the use of cross-sectional data in the context of this dynamic public controversy over refugees. Consequently, with reference to "reinforcing spirals" (Slater, 2007) and "echo chambers" (Garrett, 2009), the question of the stability of the attitude-behavior typology becomes an important issue. In future research, panel surveys should be conducted to figure out whether different segments of the German population will change their attitudes and behavior. Especially the question whether a radicalization of specific groups can be observed is of strong scientific and political interest.

Secondly, our argumentation on the role of mainstream media coverage is based on the normative expectations that the mass media should enable an open discourse and reflect a diverse range of positions and arguments from various actors. However, based on the indexing hypothesis (Bennett, 1990), one might expect the mass media primarily to reflect the views of the political elite on the refugee issue, rather than those of the broad public. Particularly during the summer of 2015, the position of all German parties represented in the national parliament (Bundestag) was quite supportive of the governmental 'welcome policy'. As the mainstream media frequently limits the scope of its coverage to the opinions of the political establishment, at least parts of the German public might have felt represented neither by the politicians nor by the media. Consequently, to adequately evaluate the audience perceptions of media bias, a combination of survey data and content analysis is needed.

Finally, the results of our study are limited to the German situation, which in many aspects is different from that of other European nations. In comparison to countries like Italy or Spain which have been directly confronted with the refugee problem for many years, in the past, Germany was less affected because of the Dublin regulation. However, the number of refugees coming to Germany in 2015 far exceeded the numbers of refugees going to all the other European countries. Furthermore, the official political positions toward refugees differed fundamentally between the European countries. While the German government decided to open its borders, many other countries implemented a much more restrictive policy, including the construction of fences at their national borders. And while national governments applied different policies, the public opinion in these countries was also vastly different. As part of the Eurobarometer 84.3, which was conducted in all 28 EU member states in November 2015, the participants were questioned to what extent they agreed or disagreed that their respective country "should help refugees". At that time, $85 \%$ of the German population was in favor of helping refugees. In comparison to many other European countries, the attitudes of Germans toward refugees were above average. But there were also some countries like Spain (88\%), the Netherlands (89\%) and Sweden (94\%), whose populations were even more supportive. Yet, in some countries, only the minority of the population supported this position. Particularly in Hungary (30\%), the Czech Republic (30\%), and Bulgaria (32\%), the willingness to help the refugees was quite low. Thus, it seems reasonable to expect that the media in different countries cover the refugee issue differently. Therefore, future research needs to investigate the role of communication about the refugee issue from an international comparative perspective. Continuously observing media coverage and public opinion on the refugee issue is obviously strongly relevant as the topic will surely remain one of the biggest European challenges for the next several years.

\section{References}


Arnold, K. (2009). Qualitätsjournalismus: Die Zeitung und ihr Publikum. Konstanz: UVK.

Bacher, J., Pöge, A., \& Wenzig, K. (2010). Clusteranalyse. Anwendungsorientierte Einführung in Klassifikationsverfahren. München: Oldenbourg.

Becker, C. (1998). The ways in which communication may foster or inhibit socialization: The Case of Brazilian immigrants in Japan. In G. Gumpertz \& S. Drucker (Eds.), The huddled masses. Communication and immigration (pp. 301-328). Cresskill, New Jersey: Hampton Press.

Bennett, W. L. (1990). Toward a theory of press-state relations in the United States. Journal of Communication, 40(2), 103-127. doi:10.1111/j.1460-2466.1990.tb02265.x

Colleoni, E., Rozza, A., \& Arvidsson, A. (2014). Echo chamber or public sphere? Predicting political orientation and measuring political homophily in Twitter using big data. Journal of Communication, 64(2), 317-332. doi:10.1111/jcom.12084

Eagly, A. H., \& Chaiken, S. (1993). The psychology of attitudes. Fort Worth: Harcourt Brace Jovanovich.

Eilders, C. (2006). News factors and news decisions. Theoretical and methodological advances in Germany. Communications, 31(1), 5-24. doi:10.1515/COMMUN.2006.002

Emmer, M., Füting, A., \& Vowe, G. (2006). Wer kommuniziert wie über politische Themen? Eine empirisch basierte Typologie individueller politischer Kommunikation. Medien \& Kommunikationswissenschaft, 54(2), 216-236.

Esses, V. M., Dovidio, J. F., Jackson, L. M., \& Armstrong, T. L. (2001). The immigration dilemma: The role of perceived group competition, ethnic prejudice, and national identity. Journal of Social Issues, 57(3), 389-412. doi:10.1111/0022-4537.00220

European Commission (2015). Eurobarometer 84.3. November 2015. TNS OPINION, Brussels; GESIS, Cologne. ZA6643, data set version 3.0.0. doi:10.4232/1.12664

European Social Survey (2015). Round 7 module on attitudes towards immigration and their antecedents - Question design final module in template. London: Centre for Comparative Social Surveys.

Everitt, B. S., Landau, S., Leese, M., \& Stahl, D. (2011). Cluster analysis (5 ${ }^{\text {th }}$ ed.). Chichester: Wiley.

Galtung, J., \& Ruge, M. (1965). The structure of foreign news. The presentation of the Congo, Cuba and Cyprus crises in four Norwegian newspapers. Journal of Peace Research, 2(1), 64-91.

Garrett, R. K. (2009). Echo chambers online?: Politically motivated selective exposure among Internet news users. Journal of Computer-Mediated Communication, 14(2), 265-285. doi:10.1111/j.1083-6101.2009.01440.x

Geissler, R., \& Pöttker, H. (2009). Media, migration, integration: European and North American perspectives. Bielefeld: Transcript.

Glasman, L. R., \& Albarracín, D. (2006). Forming attitudes that predict future behavior: A meta-analysis of the attitude-behavior relation. Psychological bulletin, 132(5), 778-822.

Hainmueller, J., \& Hopkins, D. J. (2014). Public attitudes toward immigration. Annual Review of Political Science, 17, 225-249. doi:http://dx.doi.org/10.2139/ssrn.2289270

Hasebrink, U., \& Domeyer, H. (2012). Media repertoires as patterns of behaviour and as meaningful practices: A multimethod approach to media use in converging media environments. Participations. Journal of Audience \& Reception Studies, 9(2), 757-779. doi:10.5325/jinfopoli.1.2011.0321

Hasebrink, U., \& Popp, J. (2006). Media repertoires as a result of selective media use. A conceptual approach to the analysis of patterns of exposure. Communications, 31(3), 369-387. doi:10.1515/COMMUN.2006.023 
Hefner, D. (2013). „Wie kriegen wir sie ins Boot?“ - Eine Typologie zur Entwicklung von Kommunikationsstrategien zur Förderung umweltschützenden Verhaltens ["How do we bring them on board?” - A typology for developing communication strategies for the promotion of environmental protection behavior]. Medien \& Kommunikationswissenschaft, 61(3), 387-405.

Iyengar, S., Curran, J., Lund, A. B., Salovaara-Moring, I., Hahn, K. S., \& Coen, S. (2010). Cross-national versus individual-level differences in political information: A media systems perspective. Journal of Elections, Public Opinion and Parties, 20(3), 291-309. doi:10.1080/17457289.2010.490707

Iyengar, S., \& Hahn, K. S. (2009). Red Media, Blue Media: Evidence of Ideological Selectivity in Media Use. Journal of Communication, 59(1), 19-39. doi:10.1111/j.14602466.2008.01402.x

Jungnickel, K. (2011). Nachrichtenqualität aus Nutzersicht. Ein Vergleich zwischen Leserurteilen und wissenschaftlich-normativen Qualitätsansprüchen. Medien \& Kommunikationswissenschaft, 59(3), 360-378.

Katz, E., Blumler, J. G., \& Gurevitch, M. (1974). Utilization of mass communication by the individual. In J. G. Blumler \& E. Katz (Eds.), The uses of mass communications: Current perspectives on gratifications research (pp. 19-32). Beverly Hills: Sage.

Kim, M.-S., \& Hunter, J. E. (1993). Attitude-behavior relations: A meta-analysis of attitudinal relevance and topic. Journal of Communication, 43(1), 101-142.

Kraus, S. J. (1995). Attitudes and the prediction of behavior: A meta-analysis of the empirical literature. Personality and Social Psychology Bulletin, 21(1), 58-75.

Lasswell, H. D. (1948). The structure and function of communication in society. In L. Bryson (Ed.), The communication of ideas (pp. 37-51). New York: Harper and Brothers.

Leiserowitz, A., Maibach, E., Roser-Renouf, C., \& Smith, N. (2011). Global warming's six Americas, May 2011. Yale University and George Mason University. New Haven, CT: Yale Project on Climate Change. Retrieved December 12, 2016 from http://environment.yale.edu/climate/files/SixAmericasMay2011.pdf

Maletzke, G. (2002). Integration - eine gesellschaftliche Funkion der Massenkommunikation [Integration - a societal function of mass communication]. In H. Haas \& O. Jarren (Eds.), Mediensysteme im Wandel. Struktur, Organisation und Funktionen der Massenmedien (pp. 69-76). Wien: New Academic Press.

Mastro, D. (2009). Racial/ethnic stereotyping and the media. In R. L. Nabi \& M. B. Oliver (Eds.), The SAGE handbook of media processes and effects (pp. 377-391). Los Angeles: Sage.

McKeever, B. W., Riffe, D., \& Carpentier, F. D. (2012). Perceived hostile media bias, presumed media influence, and opinions about immigrants and immigration. Southern Communication Journal, 77(5), 420-437. doi:10.1080/1041794X.2012.691602

McNair, B. (2009). Journalism and democracy. In K. Wahl-Jorgensen \& T. Hanitzsch (Eds.), The handbook of journalism studies (pp. 237-249). New York: Routledge.

McQuail, D. (1992). Media performance: Mass communication and the public interest. London: Sage.

Metag, J., Füchslin, T., \& Schäfer, M. S. (2015). Global warming’s five Germanys: A typology of Germans' views on climate change and patterns of media use and information. Public Understanding of Science. doi:10.1177/0963662515592558

Oehmichen, E., \& Ridder, C.-M. (2010). Die MedienNutzerTypologie 2.0. Aktualisierung und Weiterentwicklung des Analyseinstruments [The media user typology 2.0. Update and enhancement of the analytical instruments]. Baden-Baden: Nomos. 
Palmgreen, P., \& Rayburn, J. D., II. (1982). Gratifications sought and media exposure. An expectancy value model. Communication Research, 9(4), 561-580. doi:10.1177/009365082009004004

Patterson, T., \& Seib, P. (2005). Informing the public. In G. Overholser, K. Hall Jamieson, \& American Institutions of Democracy (Eds.), The press (pp. 189-202). Oxford: Oxford University Press.

Perloff, R. M. (2015). A three-decade retrospective on the hostile media effect. Mass Communication and Society, 18(6), 701-729. doi:10.1080/15205436.2015.1051234

Ronneberger, F. (2002). Funktionen des Systems Massenkommunikation [Functions of the mass communications system]. In H. Haas \& O. Jarren (Eds.), Mediensysteme im Wandel. Struktur, Organisation und Funktionen der Massenmedien (pp. 61-66). Wien: New Academic Press.

Rosenberg, M. J., \& Hovland, C. I. (1960). Cognitive, affective and behavioral components of attitudes. In M. J. Rosenberg, C. I. Hovland, W. J. Mc Guire, R. P. Abelson, \& J. W. Brehm (Eds.), Attitude organization and change (pp. 1-14). New Haven: Yale University Press.

Ruhrmann, G., Woelke, J., Maier, M., \& Diehlmann, N. (2003). Der Wert von Nachrichten im deutschen Fernsehen. Ein Modell zur Validierung von Nachrichtenfaktoren [The value of German TV news. A model for the validation of news factors]. Opladen: Springer.

Shoemaker, P. J., \& Reese, S. D. (2014). Mediating the message in the $21^{\text {st }}$ century: A media sociology perspective ( $3^{\text {rd }}$ ed.). New York: Routledge.

Slater, M. D. (2007). Reinforcing spirals: The mutual influence of media selectivity and media effects and their impact on individual behavior and social identity. Communication Theory, 17, 281-303.

Staab, J. F. (1990). Nachrichtenwert-Theorie: Formale Struktur und empirischer Gehalt [News value theory: Formal structure and empirical content]. Freiburg: Alber.

Stroud, N. J. (2008). Media Use and Political Predispositions: Revisiting the Concept of Selective Exposure. Political Behavior, 30(3), 341-366. doi:10.1007/s11109-007-90509

Taddicken, M., \& Reif, A. (2016). Who participates in the climate change online discourse? A typology of Germans' online engagement. Communications, 41(3), 315-337. doi:10.1515/commun-2016-0012

Tal-Or, N., Tsfati, Y., \& Gunther, A. C. (2009). The influence of presumed media influence. Origins and implications of the third-person perception. In R. L. Nabi \& M. B. Oliver (Eds.), The SAGE handbook of media processes and effects (pp. 99-112). Los Angeles: Sage.

Tartakovsky, E., \& Walsh, S. D. (2016). Testing a new theoretical model for attitudes toward immigrants: The case of social workers' attitudes toward asylum seekers in Israel. Journal of Cross-Cultural Psychology, 47(1), 72-96. doi:10.1177/0022022115613860

Vallone, R. P., Ross, L., \& Lepper, M. R. (1985). The hostile media phenomenon: Biased perception and perceptions of media bias in coverage of the Beirut Massacre. Journal of Personality and Social Psychology, 49(3), 577-585. doi:10.1037/0022-3514.49.3.577

Voigt, J. (2016). Nachrichtenqualität aus Sicht der Mediennutzer. Wie Rezipienten die Leistung des Journalismus beurteilen können. [News quality from the perspective of media users. How recipients can asses the performance of journalism.] Wiesbaden: Springer.

Westerståhl, J. (1983). Objective news reporting. Communication Research, 10(3), 403-424. doi:10.1177/009365083010003007

Wolling, J. (2009). The effect of subjective quality assessments on media selection. In T. Hartmann (Ed.), Media choice: A theoretical and empirical overview (pp. 84-101). New York: Routledge. 
Wolling, J., \& Emmer, M. (2014). Individual political communication and participation. In C. Reinemann (Ed.), Political communication (pp. 449-468). Berlin, Boston: de Gruyter.

Wright, C. R. (1960). Functional analysis and mass communication. Public Opinion Quarterly, 24(4), 605-620. doi:10.1086/266976 
Table 1: Operationalization, description, and indices of typology-building variables.

Positive attitudes towards refugees (index of four items: $\mathrm{M}=2.2 ; \mathrm{SD}=0.8$; Alpha $=.878$ )

"Refugees are a great opportunity for the economic development of Germany" (M=2.1;

$\mathrm{SD}=1.0)$.

"Refugees represent a cultural enrichment of life in Germany" $(\mathrm{M}=2.2 ; \mathrm{SD}=1.0)$.

"I can imagine refugees being part of my circle of friends" $(\mathrm{M}=2.2 ; \mathrm{SD}=1.0)$.

"By accommodating refugees, the humanitarian values of the German population are strengthened” ( $\mathrm{M}=2.3$; $\mathrm{SD}=1.0)$.

Negative attitudes towards refugees (index of four items: $\mathrm{M}=2.7 ; \mathrm{SD}=0.9$; Alpha $=.877)^{1}$

"Refugees threaten Germany’s economic wealth” $(\mathrm{M}=2.5 ; \mathrm{SD}=1.1)$.

"The presence of refugees has meant that the influence of foreign cultures in Germany has strongly increased" ( $\mathrm{M}=3.1 ; \mathrm{SD}=0.9)$.

"I perceive refugees as a threat to my immediate environment" $(\mathrm{M}=2.4 ; \mathrm{SD}=1.1)$.

"Refugees are unwilling to accept German rules and norms" (M=2.9; $\mathrm{SD}=0.9)$.

Taking actions supporting refugees (index of two items: $\mathrm{M}=0.2 ; \mathrm{SD}=0.6$; Alpha=.607)

"Participating in public demonstrations for the admission of refugees" $(\mathrm{M}=0.2 ; \mathrm{SD}=0.6)$.

"Supporting signature campaigns (also online) for the admission of refugees" $(\mathrm{M}=0.2$; $\mathrm{SD}=0.8)$.

Taking actions against refugees (index of two items: $\mathrm{M}=0.1 ; \mathrm{SD}=0.5$; Alpha $=.689)^{2}$

"Participating in public demonstrations against the admission of refugees" (M=0.1;

$\mathrm{SD}=0.6)$.

"Supporting signature campaigns (also online) against the admission of refugees" $(\mathrm{M}=0.2 ; \mathrm{SD}=0.7)$.

Taking discursive actions (index of two items: $\mathrm{M}=0.5 ; \mathrm{SD}=1.1 ;$ Alpha=.700) ${ }^{2}$ "Commenting on posts about refugees online" $(\mathrm{M}=0.7 ; \mathrm{SD}=1.4)$.

"Publishing one’s own posts about refugees online" (M=0.3; $\mathrm{SD}=1.0)$.

Communicating about refugees (sum-index of two items: $\mathrm{M}=25.1$; $\mathrm{SD}=26.3)^{3}$

"Communicating about refugees with family members and close friends" $(\mathrm{M}=14.1$;

$\mathrm{SD}=15.1)$.

"Communicating about refugees with colleagues and more distant friends" $(\mathrm{M}=11$; $\mathrm{SD}=13.7)$

Communicating with refugees (sum-index of four items: $M=7.4 ; S D=24.1)^{3}$

"Communicating with refugees in everyday situations" (e.g., buying tickets) (M=2.1;

$\mathrm{SD}=7.3)$.

"Communicating with refugees in work-related situations" $(\mathrm{M}=2.7 ; \mathrm{SD}=9.3)$.

"Communicating with refugees through public engagement $(\mathrm{M}=1.5 ; \mathrm{SD}=6.7)$.

"Communicating with refugees through close personal contact" (M=1.1; SD=5.6).

Notes: ${ }^{1}$ four-point scale (1 "totally disagree" to 4 "totally agree"); ${ }^{2}$ three-point scale ( 0 "never”, 1 “once”, 4 "several times”); ${ }^{3}$ seven-point scale reflecting the number of discussions/contacts per month (0 "never", 0.5 "less than once a month", 1 "once a month", 4 "once a week", 12 "several times a week", 30 "daily”, 60 "several times a day”. Before using them in the cluster-analysis, all variables were standardized. 
Table 2: Operationalization, description, and indices of typology-describing variables.

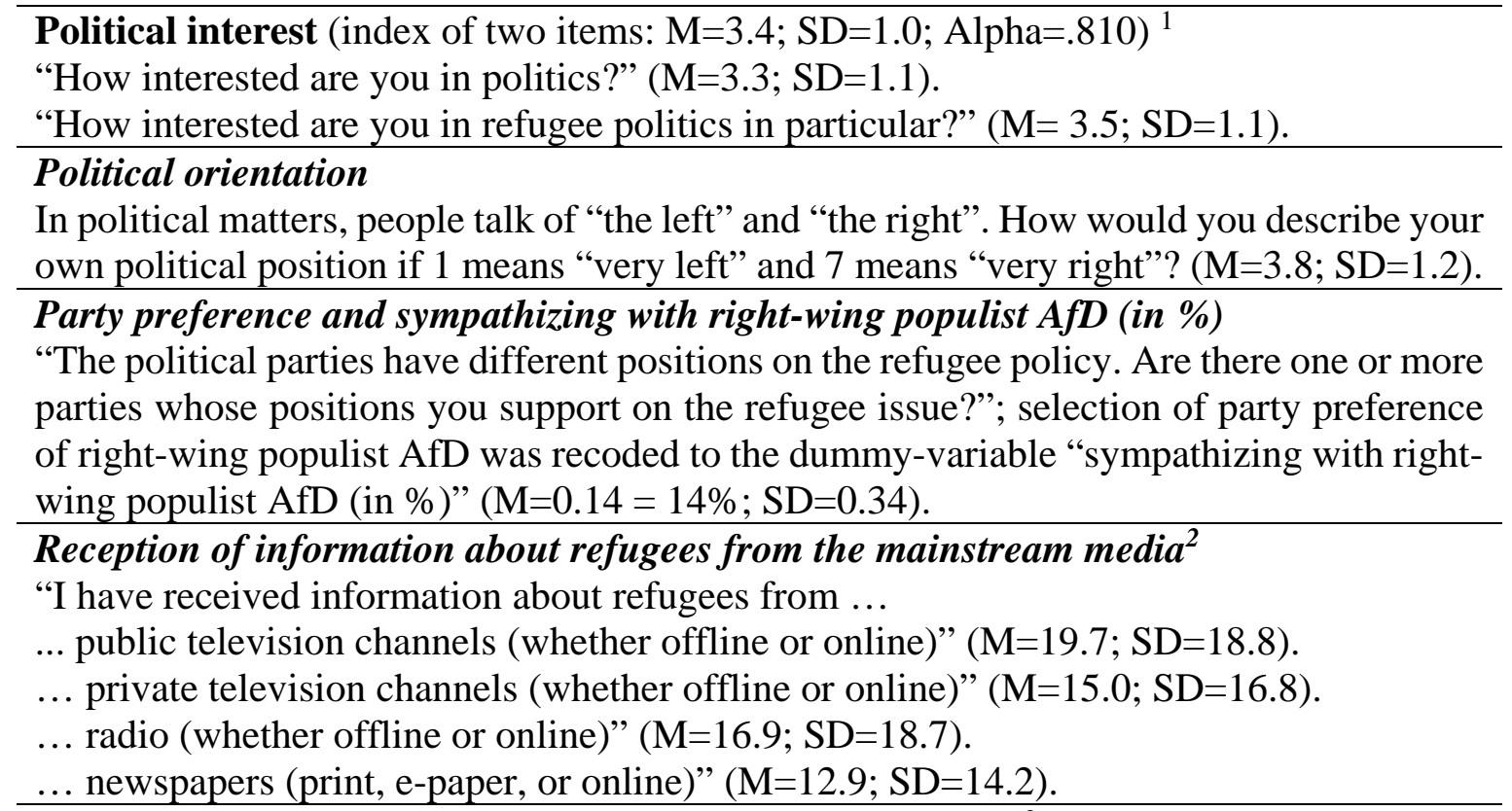

Reception of information about refugees from social media ${ }^{2}$

"I have received information about refugees from ...

... Facebook" (M=14.9; SD=20).

... Twitter" (M=2.1; $\mathrm{SD}=8.3)$.

... YouTube" (M=2.8; $\mathrm{SD}=8.5)$.

... user comments on media items" (regardless of how you became aware of them) $(\mathrm{M}=8.9 ; \mathrm{SD}=15)$.

Expectations of how journalists should cover the refugee issue $e^{3}$

"Should journalists ...

... report in a restrained or unrestrained manner on the refugee issue?" $(\mathrm{M}=0.8 ; \mathrm{SD}=0.4)$.

... emphasize opportunities or risks relating to refugees in their coverage?” $(\mathrm{M}=0.3$;

$\mathrm{SD}=0.5)$.

... emphasize the achievements or the problems of dealing with refugees in Germany?”

$(\mathrm{M}=0.4 ; \mathrm{SD}=0.5)$.

... mostly give politicians and experts a voice or the ordinary public?” ( $M=0.7 ; \mathrm{SD}=0.5)$.

... only give people with moderate attitudes on refugees a voice or also those with radical attitudes?" (M=0.4; $\mathrm{SD}=0.5)$.

Evaluations of the media coverage on the refugee issue (index of six items: $M=0.2$; $\mathrm{SD}=0.9$; Alpha $=.897)^{4}$

"What is your impression of the media's coverage of refugees over the past month? Do the media's representations match the facts, or are they distorted in one or another direction? How did the media cover the ...

... refugees' willingness to integrate in German society?” (M=0.0; $\mathrm{SD}=1.1)$.

... impacts on Germany's economic wealth?” (M=0.0; $\mathrm{SD}=1.0)$.

... government's decisions on the refugee issue?” $(\mathrm{M}=0.4 ; \mathrm{SD}=1.2)$.

... impacts on cultural life in Germany?” $(\mathrm{M}=0.1 ; \mathrm{SD}=1.0)$.

... consequences of living together peacefully in Germany?” $(M=0.0 ; S D=1.1)$.

... attitudes of the German population toward refugees?" (M= - 0.1; $\mathrm{SD}=1.1)$.

Notes: ${ }^{1}$ five-point scale (1 "very little interest" to 5 "very strong interest"); ${ }^{2}$ six-point scale reflecting the days of exposure per month (0 "never", 1 "once a month", 4 "once a week/four days per month”, 12 "several times a week/twelve days per month", 30 
“daily/thirty days per month”, 60 "several times a day”); ${ }^{3}$ answers "non-constrained”, "risks", "problems", “ordinary public" and "radical attitudes" coded as +1 ; answer "undecided/neither nor" coded 0 ; other coded as +1 ; " five-point scale ( 2 "far too negative", -1 "rather too negative", 0 "adequate", 1 "rather too positive”, 2 "far too positive”). 
Table 3: Population segments (clusters) with specific attitude-behavior combinations (means).

\begin{tabular}{|c|c|c|c|c|c|c|c|c|c|}
\hline & $\begin{array}{l}\text { Pro- } \\
\text { Refugee } \\
\text { Activists }\end{array}$ & $\begin{array}{l}\text { Passive- } \\
\text { Affirmati } \\
\text { ve } \\
\text { Mainstrea } \\
\text { m }\end{array}$ & $\begin{array}{l}\text { Directly- } \\
\text { Involved } \\
\text { Ambivale } \\
\text { nts }\end{array}$ & $\begin{array}{l}\text { Passive- } \\
\text { Worried } \\
\text { Mainstrea } \\
\text { m }\end{array}$ & $\begin{array}{l}\text { Worried } \\
\text { Agitators }\end{array}$ & $\begin{array}{l}\text { Anti- } \\
\text { Refugee } \\
\text { Activists }\end{array}$ & $\mathrm{df}$ & $\begin{array}{l}\text { F- } \\
\text { Score }\end{array}$ & $\mathrm{p}$ \\
\hline $\mathrm{N}$ (\% of sample) & $\begin{array}{l}177 \\
(12 \%)\end{array}$ & $\begin{array}{l}625 \\
(41 \%)\end{array}$ & $69(5 \%)$ & $\begin{array}{l}429 \\
(28 \%)\end{array}$ & $\begin{array}{l}199 \\
(13 \%)\end{array}$ & $40(3 \%)$ & & & \\
\hline Positive attitudes towards refugees ${ }^{1}$ & $3.2^{\mathrm{a}}$ & $2.7^{\mathrm{b}}$ & $2.5^{\mathrm{c}}$ & $1.5^{\mathrm{d}}$ & $1.5^{\mathrm{d}}$ & $1.3^{\mathrm{e}}$ & 5 & 424.1 & $<.001$ \\
\hline Negative attitudes towards refugees ${ }^{1}$ & $1.9^{\mathrm{a}}$ & $2.2^{\mathrm{b}}$ & $2.7^{\mathrm{c}}$ & $3.4^{\mathrm{d}}$ & $3.5^{\mathrm{d}}$ & $3.7^{\mathrm{e}}$ & 5 & 451.4 & $<.001$ \\
\hline Taking actions supporting refugees ${ }^{2}$ & $1.1^{\mathrm{a}}$ & $0^{\mathrm{b}}$ & $0.9^{c}$ & $0^{\mathrm{b}}$ & $0^{\mathrm{b}}$ & $0^{\mathrm{b}}$ & 5 & 195.2 & $<.001$ \\
\hline Taking actions against refugees ${ }^{2}$ & $0.1^{\mathrm{a}}$ & $0^{\mathrm{b}}$ & $0.7^{\mathrm{c}}$ & $0^{\mathrm{b}}$ & $0.1^{\mathrm{a}}$ & $2.7^{\mathrm{d}}$ & 5 & 635.2 & $<.001$ \\
\hline Taking discursive actions ${ }^{2}$ & $1.7^{\mathrm{a}}$ & $0.1^{\mathrm{b}}$ & $1.1^{\mathrm{c}}$ & $0^{\mathrm{b}}$ & $1.4^{\mathrm{d}}$ & $2.3^{\mathrm{e}}$ & 5 & 251.2 & $<.001$ \\
\hline Communicating about refugees $^{3}$ & $27^{\mathrm{a}}$ & $16^{\mathrm{b}}$ & $61^{\mathrm{c}}$ & $15^{\mathrm{b}}$ & $58^{\mathrm{c}}$ & $53^{\mathrm{d}}$ & 5 & 214.0 & $<.001$ \\
\hline Communicating with refugees $^{3}$ & $9^{\mathrm{a}}$ & $2^{\mathrm{b}}$ & $97^{\mathrm{c}}$ & $2^{\mathrm{b}}$ & $3^{\mathrm{b}}$ & $7^{\mathrm{a}}$ & 5 & 574.3 & $<.001$ \\
\hline
\end{tabular}

Notes: ${ }^{1}$ scale from 1 "low" to 4 "high"; ${ }^{2}$ five-point scale from 0 "no" to 4 "several times"; ${ }^{3}$ number of discussions/contacts per month; $\mathrm{n}=1,579$; analysis of variance: means in the same row that do not share superscripts differ at $\mathrm{p}<.05$ in the post-hoc test (Duncan).

Table 4. Cluster description: Socio-demographics, political characteristics and media-related variables.

\begin{tabular}{|c|c|c|c|c|c|c|c|c|c|}
\hline & $\begin{array}{l}\text { Pro- } \\
\text { Refuge } \\
\mathrm{e} \\
\text { Activist } \\
\mathrm{s}\end{array}$ & $\begin{array}{l}\text { Passive- } \\
\text { Affirmative } \\
\text { Mainstrea } \\
\text { m }\end{array}$ & $\begin{array}{l}\text { Directly- } \\
\text { Involved } \\
\text { Ambivalen } \\
\text { ts }\end{array}$ & $\begin{array}{l}\text { Passive- } \\
\text { Worried } \\
\text { Mainstrea } \\
\text { m }\end{array}$ & $\begin{array}{l}\text { Worried } \\
\text { Agitators }\end{array}$ & $\begin{array}{l}\text { Anti- } \\
\text { Refugee } \\
\text { Activists }\end{array}$ & $\mathrm{df}$ & $\begin{array}{l}\text { F-Score } \\
\text { Chi }^{2} *\end{array}$ & p \\
\hline Socio-demographic & & & & & & & & & \\
\hline Male (in \%) & 56 & 48 & 65 & 46 & 51 & 65 & 5 & $16.4 *$ & $<.01$ \\
\hline
\end{tabular}


Age (in years)

Higher education (in \%)

Household income ( $\varnothing$ in Euro)

$43^{\mathrm{a}} \quad 44^{\mathrm{a}}$

Living in East Germany (in \%)

\title{
Political characteristics
}

Political interest $(1=$ low; $5=$ very strong interest $) \quad 4.0^{\mathrm{a}} \quad 3.3^{\mathrm{b}}$

Political orientation (1= very left; 7= very right) $\quad 3.2^{\mathrm{a}} \quad 3.5^{\mathrm{b}}$

Sympathizing with right-wing populist AfD (in \%) 2

2

4.0
14

$38^{\mathrm{b}}$

$$
47^{\mathrm{a}}
$$

$45^{\mathrm{a}}$

$44^{\mathrm{a}}$

5

4.4

.001

Exposure to information on refugees from online and offline news sources provided by mass media in days per month $(0=$ no exposure;

1=one day per month; 30= every day a month; 60=more than once every day a month)

Public television programs

\begin{tabular}{|c|c|c|c|c|c|c|c|}
\hline $24^{\mathrm{a}}$ & $19^{b}$ & $28^{a}$ & $16^{\mathrm{b}}$ & $26^{\mathrm{a}}$ & $18^{b}$ & 5 & 12.9 \\
\hline $10^{\mathrm{a}}$ & $12^{\mathrm{ab}}$ & $21^{\mathrm{c}}$ & $15^{\mathrm{b}}$ & $26^{d}$ & $20^{c}$ & 5 & 28.9 \\
\hline $19^{\mathrm{ab}}$ & $15^{\mathrm{ab}}$ & $25^{c}$ & $14^{\mathrm{a}}$ & $25^{c}$ & $19^{b}$ & 5 & 14.4 \\
\hline $16^{\mathrm{a}}$ & $10^{\mathrm{b}}$ & $24^{c}$ & $10^{\mathrm{b}}$ & $20^{\mathrm{a}}$ & $16^{\mathrm{a}}$ & 5 & 30.5 \\
\hline
\end{tabular}

Private television programs

Radio

Newspapers

$16 \quad 10$

$\begin{array}{ll}18^{\mathrm{a}} & 11^{\mathrm{b}} \\ 3^{\mathrm{a}} & 1^{\mathrm{ab}} \\ 3^{\mathrm{ab}} & 1^{\mathrm{a}}\end{array}$

$21^{\mathrm{a}}$

$10^{\mathrm{b}}$

\begin{abstract}
$29^{c}$
\end{abstract}
$13^{\mathrm{d}} \quad 0^{\mathrm{b}}$

Twitter

YouTube

User comments on media items

$13^{\mathrm{a}} \quad 6^{\mathrm{b}}$

$13^{\mathrm{c}}$

$1^{\mathrm{a}}$

$18^{\mathrm{c}}$

$5^{b}$

4

$18^{\mathrm{c}}$

per mont

$30=$

1

Expectations of how journalists should cover the refugee issue (means)

Report restrained $=-1$; report unrestrained $=+1$

$0.66^{\mathrm{a}}$

$0.75^{b}$

$0.81^{b}$

$0.90^{\mathrm{c}}$

$0.92^{\mathrm{c}}$

$0.93^{\mathrm{C}}$

5

$\begin{array}{ll}45.2 & <.00 \\ & 1 \\ 35.7 & <.00 \\ & 1 \\ 44.1 & <.00 \\ & 1 \\ 48.4 & <.00 \\ & 1 \\ & \\ 17.7 & <.00 \\ & 1\end{array}$




\begin{tabular}{|c|c|c|c|c|c|c|c|c|c|}
\hline Emphasize opportunities $=-1$; emphasize risks $=+1$ & $0.06^{\mathrm{a}}$ & $0.12^{\mathrm{a}}$ & $0.36^{\mathrm{b}}$ & $0.61^{\mathrm{c}}$ & $0.67^{\mathrm{c}}$ & $0.85^{\mathrm{d}}$ & 5 & 127.1 & $\begin{array}{l}<.00 \\
1\end{array}$ \\
\hline $\begin{array}{l}\text { Give voice just to moderates }=-1 \text {; give voice also to } \\
\text { radicals }=+1\end{array}$ & $0.31^{\mathrm{a}}$ & $0.30^{\mathrm{a}}$ & $0.39^{\mathrm{a}}$ & $0.48^{\mathrm{b}}$ & $0.63^{\mathrm{b}}$ & $0.88^{\mathrm{c}}$ & 5 & 24.0 & $\begin{array}{l}<.00 \\
1\end{array}$ \\
\hline \multicolumn{10}{|c|}{ Evaluations of media coverage on the refugee issue (means) } \\
\hline
\end{tabular}

Notes: analysis of variance: means in the same row that do not share superscripts differ at $\mathrm{p}<.05$ in the post-hoc test (Duncan). 